\title{
The Restructuring of the European Pharmaceutical Industry between 2000 and $2018^{1}$
}

\author{
Benedek Nagy (iD) https://orcid.org/0000-0001-5472-0423 \\ Ph.D., assistant professor, University of Szeged, Faculty of Economics and Business \\ Administration, Szeged, Hungary, e-mail: nagy.benedek@eco.u-szeged.hu
}

\begin{abstract}
To meet the requirements of global competition, the European Union (EU) places particular emphasis on the development of knowledge-intensive, innovative industries. The pharmaceutical industry, as a high-tech manufacturing subsection, has a long tradition in Europe. However, the distribution of pharmaceutical industry employment and value added is not even within the Union, and its temporal dynamics is also different.

In the present paper, I examine the change of the structure of the pharmaceutical industry within the Union using country groups. I compare the development of pharmaceutical industry employment in the period between 2000 and 2018 in three country groups. I use a simple decomposition method to separate the effects of sector growth and labor productivity change on the change of pharmaceutical employment to find out how similarly this industry evolved in the different country groups. The analysis shows that while in the 12 original, i.e., pre-2004, member states (Core EU), employment slightly increased alongside a considerable increase in value added, the nine post-socialist countries (PS9) achieved slightly greater value added expansion combined with substantial employment growth. Meanwhile, the four Visegrád countries (V4) achieved a value added growth similar to the PS9, but an even greater employment growth. This indicates that the part of the pharmaceutical industry operating with higher labor productivity is concentrating in the Core EU countries, while in the less developed post-socialist countries, the part of the pharmaceutical industry with lower labor productivity is developing.
\end{abstract}

Keywords: pharmaceutical industry, labor productivity, growth, Visegrád countries

JEL: I18, L65, O14

1 This research was supported by the EU-funded Hungarian grant EFOP-3.6.1-16-2016-00008. 


\section{Introduction}

The European pharmaceutical industry employed close to 600,000 people in 2018 , and its output contributed about 100 billion euros to GDP in real terms of $2005 .^{2}$ Within the global pharmaceutical industry, the European pharmaceutical industry is the second most important, lagging behind the Asian but ahead of the North American (Albu et al. 2016). The transformation of the global economy (development of global value chains, the start of the $4^{\text {th }}$ industrial revolution) also affected the European manufacturing industry. The outsourcing of more labor-intensive activities with low value added resulted in a kind of deindustrialization in the European Union (EU) (Fujita and Thisse 2009; Coad and Vezzani 2017).

At the same time, a new ambition of the Union is to "revive" industry through the Europe 2020 strategy announced in 2010 (European Commission 2010), and one of its objectives is to increase the share of the manufacturing industry to GDP from 15\% to $20 \%$. According to researchers of reindustrialization, the main engine of economic growth is the manufacturing industry (Tregenna 2013; Cantore et al. 2017). Thus its growth in terms of employment and produced value added stimulates slowed-down economic growth. Nevertheless, it is not sufficient to support and encourage the development of the manufacturing industry in general, and the Union, reading the signs of the time, does not simply aim for this but focuses on smart, sustainable, and inclusive growth (European Commission 2010), the digitalization of the industry, and the full-fledged utilization of the potentials of a single digital market (European Commission 2016). Consequently, the development of the manufacturing industry is of great importance to the Union, prioritizing a knowledge-intensive, high-tech manufacturing industry that builds on state-of-the-art technology. These characteristics perfectly describe the pharmaceutical industry.

In this paper, I aim to present the development of the European pharmaceutical industry. The analysis is mainly descriptive when I analyze the temporal development of some key variables defining the pharmaceutical industry in the EU and its three country groups. I study the causes of the change in the number of persons employed in the pharmaceutical industry only insofar as the decomposition method widely applied in the reindustrialization literature allows.

Before analyzing the temporal changes in production, employment, and labor productivity in the pharmaceutical industry, I would like to briefly introduce some unique aspects of the pharmaceutical industry as a special manufacturing subsection. ${ }^{3}$ In terms of the demand side, a special characteristic of the market is that the actual decision-maker is not the final consumer but the doctor prescribing the medicinal

2 The source of data is the EUROSTAT, see below.

3 About global pharmaceutical market, see Schweizer and Lu (2018). Furthermore, a research report prepared for the Commission (ECORYS 2009) provides details about the EU pharmaceutical market and its actors. 
product. ${ }^{4}$ At the same time, neither of them bears the total costs directly, but a significant part is borne by various national health insurance systems. In terms of the supply side, one significant characteristic of the market is the (price) competition between two specific groups of actors: the innovative pharmaceutical companies and the producers of generic products.

One important task of innovative producers is to develop and market new medicinal products, active substances, and molecules, which require considerably higher research and development expenses compared to other manufacturing industries. In the protection of new knowledge produced by $\mathrm{R} \& \mathrm{D}$, the pharmaceutical industry relies heavily on patent protection. Cohen, Nelson, and Walsh (2000) pointed out that the pharmaceutical industry is where this kind of intellectual property rights plays the most prominent role. Therefore, innovative manufacturers can delay generic producers' entry to the market by optimizing their patenting strategy while generating the highest possible income. In the final report of the inquiry into the pharmaceutical industry sector started in 2008, ${ }^{5}$ the European Commission established that innovative manufacturers restrict competition, and thereby the innovative capability of the industry decreases, although this statement is debated by members of the innovative sector. ${ }^{6}$

The pharmaceutical industry is further characterized by being strongly concentrated; the above-mentioned sector inquiry asked 43 innovative and 27 generic manufacturers, and they produced $80 \%$ of the relevant Union turnover. Patents are not the only reason why this market can be considered strongly regulated: the producers can often sell their products at officially determined prices (Garattini, Curto, and Freemantle 2016). Not to mention the strict regulations on testing and introducing medicinal products developed for human treatment (which is one of the reasons why the development period of new medicinal products is $10-15$ years and costs about 1 billion euros 7 ).

The Commission document, based on the findings of the inquiry, highlights three important areas for building the strategic vision for the pharmaceutical industry: advancement towards a unified and sustainable pharmaceutical market, addressing the possibilities and challenges represented by globalization, and putting science in the service of European patients (European Commission 2008, p. 4). The Commission directive outlines the Union's action plan related to the pharmaceutical industry along 22 specific objectives, the first area of which is targeted at changing the regulatory environment to be more favorable for the sector. The second area refers to the management of changing market environment created by global competition, while the third area is about research and development. The Commission expresses its conviction that

4 Of course, the consumer, i.e., the patient, can still decide not to get their prescription filled (Vajda, Horváth, and Málovics 2012).

5 http://ec.europa.eu/competition/sectors/pharmaceuticals/inquiry/communication_hu.pdf (accessed: 29.05.2018).

6 For example, Arthur Higgins, President of European Federation of Pharmaceutical Industries and Associations (EFPIA) (Presentation of the Preliminary Report..., 2008).

7 From Higgins's presentation referred to above. 
the EU has the appropriate instruments to create a dynamic and competitive pharmaceutical industry sector: "a strong research base, a renowned education system and skilled workforce, a well-established and innovative EU-based industry." (European Commission 2008, p. 16). Around the very beginning of the global financial crisis, the pharmaceutical industry reached a so-called patent cliff, i.e., in a short period, many patents related to basic medicines and molecules expired, opening the way for generics with a lower price. However, due to the continuous aging of the European continent, extensive community funding, and the low price sensitivity of the demand for pharmaceutical industry products, the decline of the EU's pharmaceutical industry failed to happen, and analysts do not expect it to take place in the near future (European Commission 2014).

\section{The situational picture of the manufacturing, high-tech manufacturing, and pharmaceutical industries}

The pharmaceutical industry is one of the high-tech manufacturing subsections within the manufacturing industry (section C). ${ }^{8}$ Below, I examine the development of gross value added (GVA) and employment in the total national economy, manufacturing, its high-tech subsections, and the pharmaceutical industry, and with their help, I look at the temporal change of two additional indicators, labor productivity and share within a larger unit (e.g., that of the pharmaceutical industry within high-tech subsections). The basic data are from Eurostat nama_10_a64 (value added) and nama_10_a64_e (employment) databases.

In the examination of the development of these indicators, I break down the entire Union into country groups and then separate and compare three groups: the twelve original member states (Core EU), ${ }^{9}$ nine post-socialist member countries (PS9), ${ }^{10}$ and the four Visegrád countries (V4). ${ }^{11}$ It needs to be noted in the following analysis that the group of V4 countries is a subset of the PS9 countries. The analyzed period is be-

8 High-tech industries in the two-digit NACE Rev.2. classification are defined as the C21 (pharmaceutical industry) and C26 (manufacturing of computer, electronic and optical products) subsections by Eurostat.

9 National data about the pharmaceutical industry GVA are not available for Sweden and Luxembourg, so they are excluded from the sample. National data for Ireland are only available up to 2014, so I decided to exclude Ireland as well. For the years that consolidated EU15 data are available from Eurostat, the pharmaceutical industry of the remaining 12 countries (Denmark, Germany, Greece, Spain, France, Italy, Netherland, Austria, Portugal, Finland and the United Kingdom) together makes up 82-86\% of EU15 pharmaceutical GVA figure and $91-95 \%$ of the EU15 employment figure.

10 For Estonia, there is no data related to the pharmaceutical industry, thus I analyzed the indicators of the remaining nine post-socialist member states (Bulgaria, Czechia, Latvia, Lithuania, Hungary, Poland, Romania, Slovenia, and Slovakia).

11 These are Czechia, Hungary, Poland and Slovakia. 
tween 2000 and 2018. For a description of the long-term evolutional history of the pharmaceutical industry, see Malerba and Orsenigo (2015).

First, let us look at the development of employment in the different country groups at different NACE Rev. 2 levels. While total employment increased to an almost identical extent in the Core EU and in the V4 countries over the course of the examined 18 years (by about 13\%), in the PS9 countries, it was about a fourth of this rate (by $3 \%$ ). Manufacturing employment significantly increased in the V4 countries (by 10\%), while in the PS9 countries, it stagnated, and in the Core EU countries, it decreased about $17 \%$. The change in employment in the high-tech sectors shows a similar pattern: $8 \%$ growth in the V4 countries, smaller growth (4\%) in the PS9 countries, and a dynamic decline (18\%) in the Core EU countries. Pharmaceutical industry employment saw an $8 \%$ increase in the Core EU countries, a 20\% increase in the PS9 countries, and a spectacular 35\% increase in the V4 countries. In terms of employment, the pharmaceutical industry is a dynamically developing subsection in the V4 and PS9 countries, its growth exceeding that of the high-tech sector, the total manufacturing industry, and the total national economy. While in manufacturing employment there was a strong decrease for each country group in 2008-2010 with not much of a recovery, pharmaceutical employment - especially in the new member states - follows a different path. There is dynamic growth between 2002 and 2009, a sudden fall in 2010, and then a quick recovery until 2012.

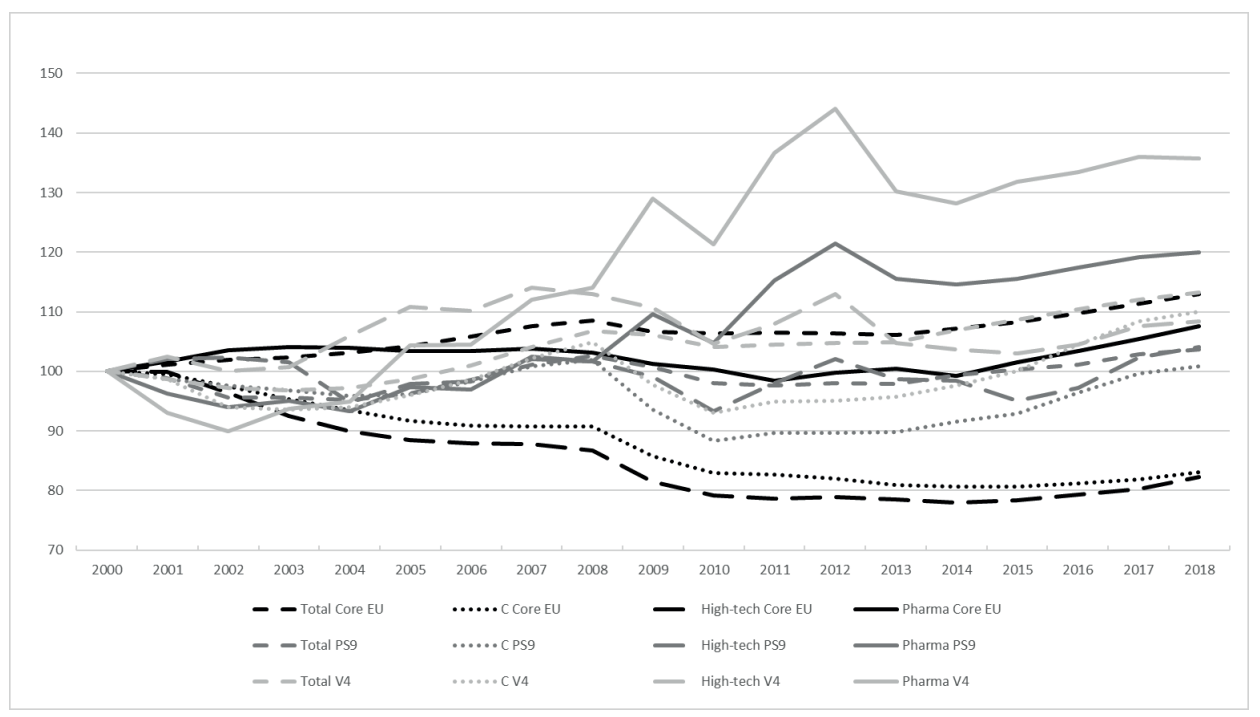

Figure 1. Comparing the employment growth of country groups, $2000-2018(2000=100)$ Source: Eurostat nama_10_a64_e.

The development of value added is illustrated in Figure 2. The development of the total national output indicated by the briefly dashed line provides the benchmark. The values of the PS9 and V4 countries move closely together in this respect, and the 
value added of the national economy of these two groups increases to a larger extent compared to the Core EU country group. In the manufacturing industry (dotted line), the difference is even more evident. The manufacturing industry of the Core EU showed very small growth throughout the examined period (18\% over 18 years), while in the two other country groups, the growth of the manufacturing industry is of much greater extent (156\% in the PS9 group, and 157\% in the V4 group). The impact of the crisis is evident on the manufacturing performance of each country group in 2009, and each decreased to a greater extent than total GVA. Pharmaceutical GVA fell a little in the Core EU countries during the financial crisis and has grown slowly but steadily ever since. In the PS9 and V4 pharmaceutical output, however, there was dynamic growth until 2010, then basically a stagnating period until 2017. The strongest growth can be seen in high-tech manufacturing subsections: this value is the highest for each country group, and it is particularly high in the PS9 countries but even more so in the V4 countries. The growth of the pharmaceutical industry falls short of these outstanding values, indicating that within the high-tech subsections, the key sector is not pharmaceuticals.

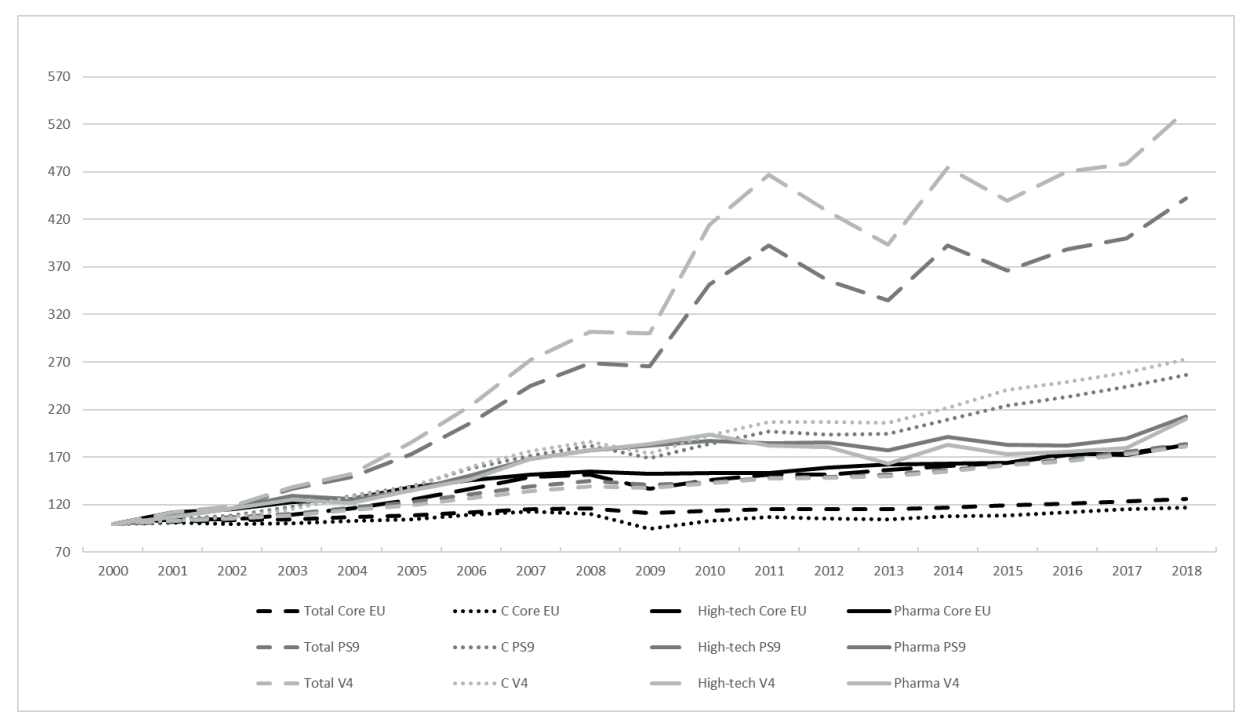

Figure 2. Comparing the GVA growth of country groups in real terms of 2005, 2000-2018 $(2000=100)$ Source: Eurostat nama_10_a64.

We can analyze two additional indices with the help of employment and value added data. First, let us look at the development of labor productivity calculated as value added per person employed.

In the assessment of the differences found in the growth of labor productivity, it has to be kept in mind that each country group started from quite different bases: the Core EU had a 4-6-fold labor productivity advantage in 2000 compared to the PS9 
countries, and somewhat less compared to V4 countries. In terms of the total economy, in the manufacturing industry, and high-tech manufacturing subsections, in particular, labor productivity grew to a greater extent in the PS9 and V4 countries than in Core EU, and the gap in labor productivity decreased in these categories. In the case of the pharmaceutical industry, however, even though the GVA growth in the PS9 and V4 countries exceeded that of the Core EU, the fourfold labor productivity advantage of Core EU in 2000 decreased slightly vis-à-vis the PS9 countries by 2018, and even increased to a fivefold advantage against the V4 countries. Finally, let us examine how the shares of the manufacturing, high-tech manufacturing, and pharmaceutical industries developed in terms of both employment and value added.

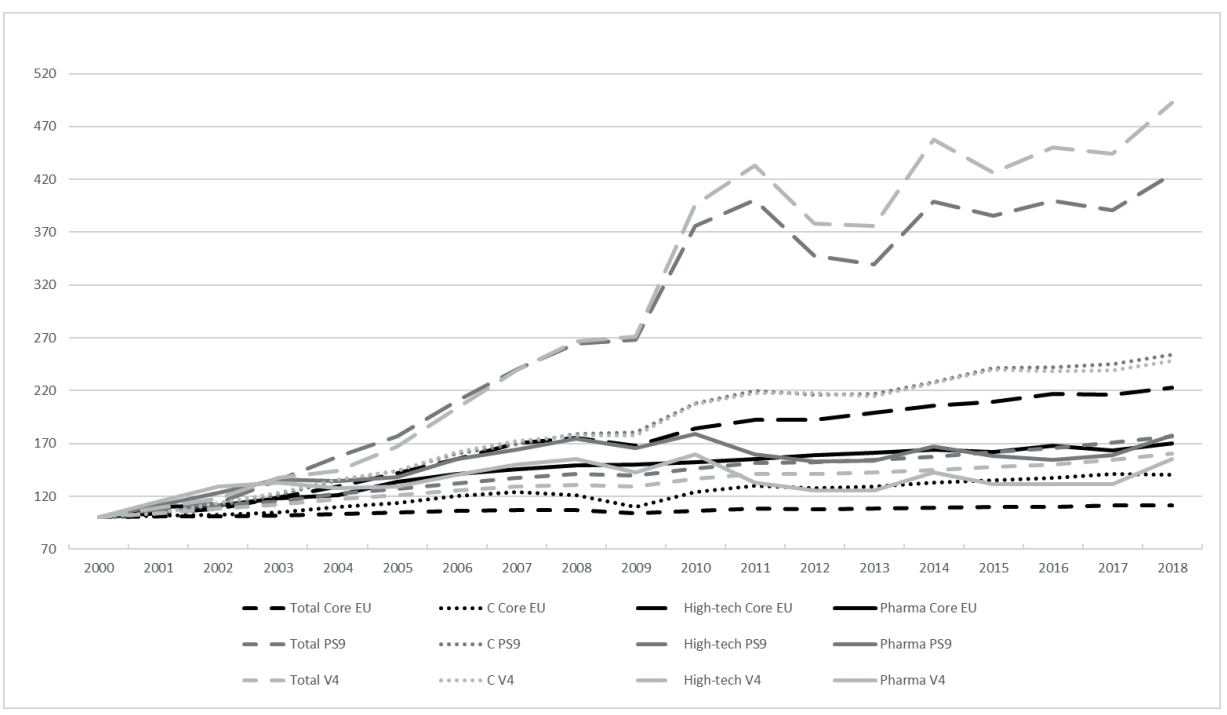

Figure 3. Development of labor productivity (value added per person employed) in the examined country groups $(2000=100)$

Source: Eurostat nama_10_a64 and nama_10_a64_e.

Table 1. Comparing country groups based on their share (\%) of the manufacturing, high-tech manufacturing, and pharmaceutical industries

\begin{tabular}{|l|l|r|r|r|r|r|r|r|r|}
\cline { 3 - 11 } \multicolumn{2}{c|}{} & \multicolumn{4}{c|}{ Employment } & \multicolumn{5}{c|}{ GVA } \\
\cline { 2 - 11 } \multicolumn{2}{c|}{} & $\mathbf{2 0 0 0}$ & $\mathbf{2 0 0 8}$ & $\mathbf{2 0 1 0}$ & $\mathbf{2 0 1 8}$ & $\mathbf{2 0 0 0}$ & $\mathbf{2 0 0 8}$ & $\mathbf{2 0 1 0}$ & $\mathbf{2 0 1 8}$ \\
\hline \multirow{2}{*}{$\begin{array}{l}\text { The manufacturing industry } \\
\text { within total national econ- } \\
\text { omy }\end{array}$} & Core EU & 16.6 & 13.9 & 12.9 & 12.2 & 18.4 & 15.6 & 14.8 & 15.1 \\
\cline { 2 - 11 } & PS10 & 21.1 & 21.0 & 19.0 & 20.6 & 20.6 & 20.6 & 20.0 & 20.6 \\
\cline { 2 - 11 } & V4 & 22.6 & 22.2 & 20.2 & 21.9 & 20.6 & 20.5 & 19.6 & 21.1 \\
\hline \multirow{2}{*}{$\begin{array}{l}\text { The high-tech manufactur- } \\
\text { ing industry within manu- } \\
\text { facturing }\end{array}$} & Core EU & 5.7 & 5.4 & 5.4 & 5.6 & 10.4 & 10.6 & 10.8 & 10.4 \\
\cline { 2 - 11 } & PS10 & 4.5 & 4.5 & 4.8 & 4.7 & 6.5 & 6.8 & 7.7 & 6.6 \\
\cline { 2 - 10 } & V4 & 4.9 & 5.3 & 4.6 & 4.9 & 6.3 & 7.1 & 7.6 & 7.1 \\
\hline
\end{tabular}


Table 1. (continued)

\begin{tabular}{|l|l|r|r|r|r|r|r|r|r|}
\cline { 3 - 12 } \multicolumn{1}{c|}{} & \multicolumn{4}{c|}{ Employment } & \multicolumn{5}{c|}{ GVA } \\
\cline { 3 - 12 } & 2000 & 2008 & 2010 & 2018 & 2000 & 2008 & 2010 & 2018 \\
\hline \multirow{2}{*}{$\begin{array}{l}\text { The pharmaceutical indus- } \\
\text { try within the manufactur- } \\
\text { ing industry }\end{array}$} & Core EU & 1.5 & 1.7 & 1.8 & 1.9 & 4.0 & 5.0 & 5.3 & 5.2 \\
\cline { 2 - 12 } & PS10 & 1.0 & 1.0 & 1.2 & 1.2 & 2.6 & 2.4 & 2.8 & 2.5 \\
\cline { 2 - 12 } & V4 & 1.0 & 1.1 & 1.3 & 1.2 & 2.4 & 2.4 & 2.9 & 2.5 \\
\hline
\end{tabular}

Note: GVA shares are calculated from nominal GVA

Source: Eurostat nama_10_a64 and nama_10_a64_e.

We can see that while in the Core EU the share of the manufacturing industry decreased in both value added and employment, the PS9 and V4 countries are characterized by a slightly increasing share of the manufacturing industry in value added, coupled with a similarly small decrease in employment share. Within the manufacturing industry, the high-tech subsections produce a higher share of value added, but they employ a decreasing share of people (as is also indicated by the growing labor productivity seen earlier). On the other hand, the pharmaceutical industry's share is increasing in both employment and value added within the manufacturing industry in all three country groups. The pharmaceutical industry in the Union, however, is not only important because it produces value added or employs people but is also an important contributor to exports. Between 2000 and 2018, the Core EU countries' export of the manufacturing industry increased from 1944 billion euros to 3524 billion euros (which is an increase of about $80 \%$ ), while their pharmaceutical industry exports expanded from 65 billion euros to 282 billion over the same period (which means an expansion of 330\%) (EUROSTAT ${ }^{12}$ ). While the global financial crisis halted the growth of manufacturing exports in all country groups, pharmaceutical exports continuously grew during the whole period.

\section{Reindustrialization or deindustrialization: growth or decline}

The reindustrialization literature mostly defines reindustrialization or deindustrialization in terms of the above-examined indicators, value added and employment. Reindustrialization or deindustrialization can only be shown for the entire manufacturing industry; this concept cannot be interpreted in the case of a single subsection. The method of decomposition, however, can be applied to a subsection to present its course of development. Here, I examine the evolution of the indicator for the level of persons employed.

The decomposition breaks down the percentage growth of employment in the pharmaceutical industry subsection into two components: labor intensity effect (by what percentage and in what direction employment changed only because labor produc-

12 Online data code: DS-018995. 
tivity changed in the subsection) and sector growth effect (by what percentage and in what direction employment changed only because the subsection produced higher value added) according to the following formula:

$$
\frac{L_{t+1}-L_{t}}{L_{t}} \cdot 100=\left[\left(\Phi_{t+1}-\Phi_{t}\right)\left(\frac{Q_{t+1}+Q_{t}}{2}\right) \cdot \frac{100}{L_{t}}\right]+\left[\left(Q_{t+1}-Q_{t}\right)\left(\frac{\Phi_{t+1}+\Phi_{t}}{2}\right) \cdot \frac{100}{L_{t}}\right],
$$

where $\Phi=L / Q$ is labor intensity, the reciprocal of labor productivity. For more technical details of the method, see Tregenna (2013) or Nagy and Lengyel (2016). The first term of the sum on the right is the labor intensity effect, and the second is the sector growth effect. A negative labor intensity effect indicates improving labor productivity; thus, it results in a decrease in employment (fewer employees could produce the same value added). A negative sector growth effect shows the shrinkage of the subsection, and it also results in a decrease in employment (lower value added can be produced by fewer people employed). It should be noted that, in a similar way, Cantore et al. (2017) conducted a decomposition of value added growth into the number of employees and labor productivity components, while McMillan and Rodrik (2011) used the decomposition of labor productivity into the factors of value added and the number of employees. The indicators used are identical in each of these papers, and the basic idea of the method is also the same; the main difference is in the selection of the indicator to be decomposed. The decomposition method is more of a descriptive method, not appropriate for discovering causal relationships.

Table 2. Change and decomposition of employment (\%)

\begin{tabular}{|c|c|c|c|c|c|c|}
\hline & \multicolumn{3}{|c|}{$2000-2008$} & \multicolumn{3}{|c|}{$2010-2018$} \\
\hline & $\begin{array}{c}\text { Change } \\
\text { of employment } \\
\text { in \% }\end{array}$ & $\begin{array}{l}\text { Labor } \\
\text { intensity } \\
\text { effect }\end{array}$ & $\begin{array}{l}\text { Sector } \\
\text { growth } \\
\text { effect }\end{array}$ & $\begin{array}{c}\text { Change } \\
\text { of employment } \\
\text { in } \%\end{array}$ & $\begin{array}{l}\text { Labor } \\
\text { intensity } \\
\text { effect }\end{array}$ & $\begin{array}{l}\text { Sector } \\
\text { growth } \\
\text { effect }\end{array}$ \\
\hline CoreEU & 3.2 & -42.2 & 45.4 & 7.3 & -11.3 & 18.5 \\
\hline V4 & 14.1 & -49.1 & 63.2 & 11.9 & 3.1 & 8.8 \\
\hline PS9 & 1.6 & -59.3 & 60.9 & 14.5 & 0.8 & 13.7 \\
\hline $\mathrm{CZ}$ & 42.8 & 4.0 & 38.8 & 11.2 & -5.4 & 16.6 \\
\hline $\mathrm{HU}$ & -25.9 & -67.1 & 41.2 & -3.0 & 12.2 & -15.2 \\
\hline $\mathrm{PL}$ & 99.3 & -25.3 & 124.6 & 23.6 & -5.4 & 29.1 \\
\hline SK & -38.8 & -56.8 & 18.0 & -2.2 & 39.3 & -41.5 \\
\hline $\mathrm{BE}$ & 25.7 & -26.5 & 52.2 & 25.7 & -5.3 & 31.0 \\
\hline DK & 54.5 & 18.9 & 35.6 & 33.3 & -56.0 & 89.3 \\
\hline$D$ & 7.3 & -53.8 & 61.0 & 12.7 & -5.7 & 18.4 \\
\hline GR & 32.2 & 36.6 & -4.4 & -19.6 & -34.7 & 15.1 \\
\hline $\mathrm{E}$ & 8.3 & -61.4 & 69.7 & 6.9 & -36.9 & 43.8 \\
\hline $\mathrm{F}$ & 19.6 & -32.7 & 52.3 & -8.0 & -26.9 & 18.9 \\
\hline 1 & -5.1 & -33.8 & 28.6 & -0.2 & -12.4 & 12.2 \\
\hline $\mathrm{NL}$ & 0.0 & -19.4 & 19.4 & -18.8 & -56.7 & 38.0 \\
\hline
\end{tabular}


Table 2. (continued)

\begin{tabular}{|c|c|c|c|c|c|c|}
\hline & \multicolumn{3}{|c|}{ 2000-2008 } & \multicolumn{3}{|c|}{$2010-2018$} \\
\hline & $\begin{array}{c}\text { Change } \\
\text { of employment } \\
\text { in } \%\end{array}$ & $\begin{array}{l}\text { Labor } \\
\text { intensity } \\
\text { effect }\end{array}$ & $\begin{array}{l}\text { Sector } \\
\text { growth } \\
\text { effect }\end{array}$ & $\begin{array}{c}\text { Change } \\
\text { of employment } \\
\text { in \% }\end{array}$ & $\begin{array}{l}\text { Labor } \\
\text { intensity } \\
\text { effect }\end{array}$ & $\begin{array}{l}\text { Sector } \\
\text { growth } \\
\text { effect }\end{array}$ \\
\hline$A$ & 4.9 & -3.2 & 8.0 & 37.4 & 6.6 & 30.8 \\
\hline$P$ & -23.3 & -42.8 & 19.5 & 33.7 & -14.2 & 47.9 \\
\hline SF & -2.2 & -57.0 & 54.8 & 15.0 & -30.4 & 45.4 \\
\hline UK & -26.2 & -61.6 & 35.4 & 6.2 & 33.6 & -27.5 \\
\hline$B G$ & -32.3 & -50.4 & 18.1 & 24.0 & -22.9 & 46.9 \\
\hline LV & 4.7 & -91.1 & 95.8 & 17.6 & 10.8 & 6.8 \\
\hline LT & -21.6 & -24.7 & 3.1 & 190.0 & 160.0 & 30.0 \\
\hline RO & -27.8 & -60.5 & 32.8 & -1.4 & 1.2 & -2.6 \\
\hline SLO & 7.4 & -70.5 & 77.8 & 37.4 & 8.1 & 29.3 \\
\hline
\end{tabular}

Source: own construction based on Eurostat data and own calculations.

The comparison of country groups shows that Core EU, PS9, as well as V4 countries, have improving labor productivity and a growing pharmaceutical industry subsection in the period before the crisis. As a result of these two changes affecting employment in the opposite direction, pharmaceutical industry employment increased in all country groups. Nevertheless, the situation considerably altered after the crisis. In the Core EU countries, pharmaceutical employment still increased with improving labor productivity, with value added increasing to a much smaller extent than in the first period. Although employment increased in the post-socialist and Visegrád countries, the factors causing this have changed a great deal: pharmaceutical sector growth was much smaller than in the first period, while productivity growth almost disappeared (small positive labor intensity effect, see also Figure 3).

By putting the two effects on coordinate axes, we can compare the development of the pharmaceutical industry in the examined country groups and countries more graphically. By putting labor intensity effect on the horizontal axis and sector growth effect on the vertical axis, the observations can be easily categorized. In the countries that are above the straight line passing through the origin with a slope of -1 , the total effect is positive, i.e., pharmaceutical industry employment grows in the examined period. In the countries below the straight line, pharmaceutical industry employment decreases.

The countries above and below the straight line can be further divided into three subcategories. In those countries above the straight line but located in the second quadrant (for example, Belgium or Slovenia in Figure 4), employment increases concomitantly with improving labor productivity. We can consider this to be the most favorable type of growth. Less favorable is the type of growth when the subsection GVA grows in parallel with decreasing labor productivity. The point signifying the countries that show such growth would be in the first quadrant (Czechia and Denmark). The most unfavorable type of subsection employment growth is when decreasing value added is paired with, and is offset by, declining labor productivity (such as in the 
case of Greece). Decreasing subsection employment, i.e., the decline of the subsection, can also be described in three ways. The most favorable case is when labor productivity improves and value added expands, but the latter effect cannot overcompensate for the former. Countries experiencing such an employment decline will be under the straight line in the second quadrant in Figure 4 (e.g., Hungary or the United Kingdom). If improving labor productivity is combined with decreasing subsection GVA, they are placed in the third quadrant. The subsection declines in the most unfavorable way if it can be characterized by deteriorating labor productivity and decreasing value added; in this case, the country is located in the fourth quadrant below the indicated straight line. There are no countries belonging to the last two categories in the period before the crisis. The majority of the analyzed countries are found in the second quadrant, suggesting that the pharmaceutical industry is increasingly less labor-intensive, and labor productivity is increasingly higher.

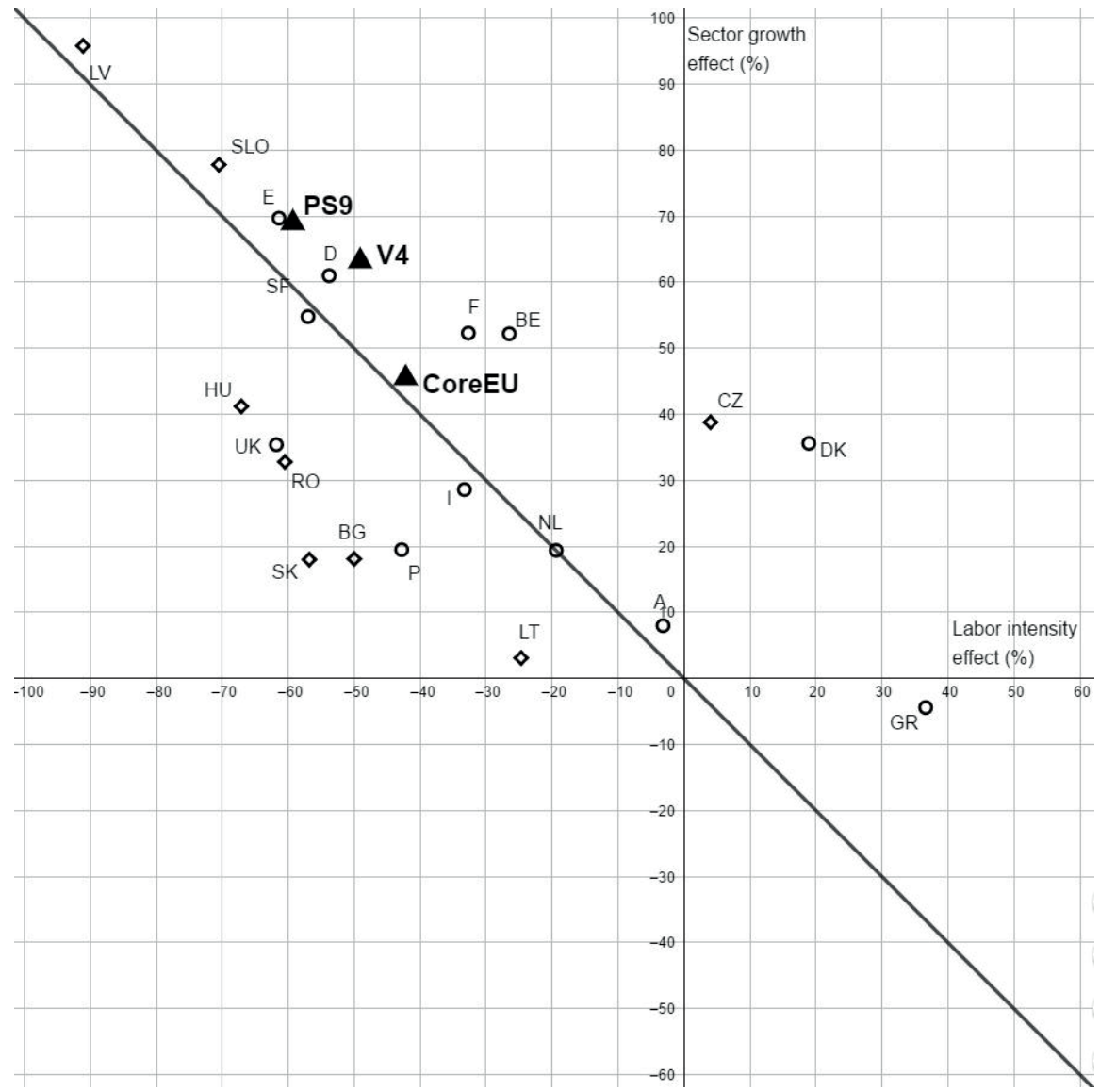

Figure 4. The examined countries and country groups based on labor intensity effect and sector growth effect (2000-2008)

Source: own construction based on Eurostat data and own calculations. 
After the crisis, the analyzed countries show a much more diverse development pattern. We can find example countries in five of the six above mentioned categories in the period of 2010-2018.

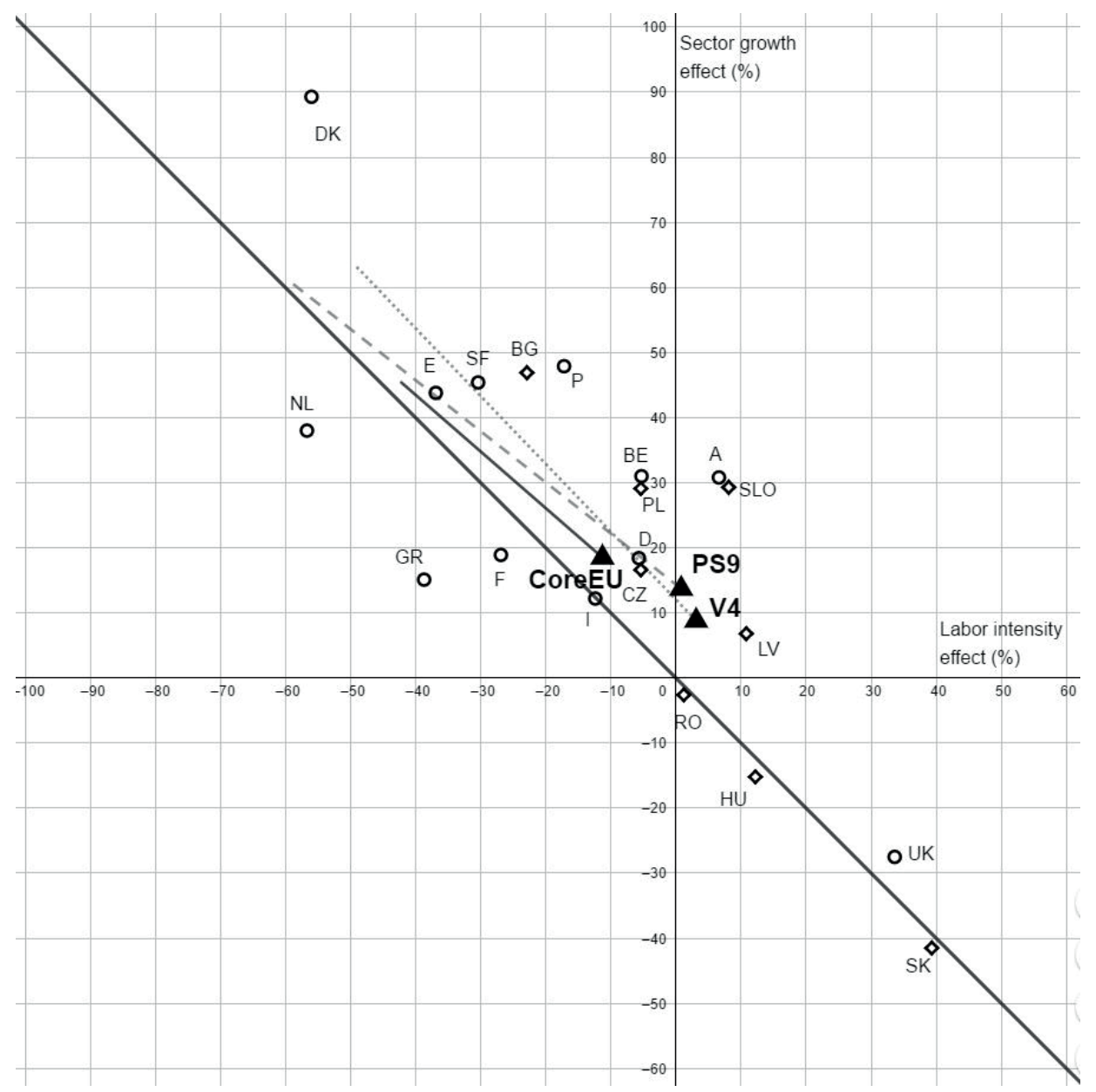

Figure 5. The examined countries and country groups based on labor intensity effect and sector growth effect (\%, 2010-2018)

Note: lines from the CoreEU, PS9, and V4 groups show the movement of these data points from the previous period

Source: own construction based on Eurostat data and own calculations.

The most favorable growth is still experienced by, for instance, Belgium, Denmark, and Portugal. However, these countries have quite a low share of the Union's pharmaceutical industry employment (and also of GVA). While this continuous growth can be useful from the perspective of the individual country (the pharmaceutical industry is relatively overrepresented in Belgium and Denmark), from the perspective of the 
entire Union's pharmaceutical industry, it is less significant. What happens with the pharmaceutical industry in Germany may be much more important, as it provided $30 \%$ of the Core EU's pharmaceutical industry employment by 2018. In Germany, the C21 subsection shows growth in employment consistently higher than the Core EU, as a combination of decreasing labor productivity and increasing value added in both periods: as mentioned above, this is the most favorable type of employment growth pattern. The V4 country group, including Poland (where $58 \%$ of people employed in the pharmaceutical industry of V4 countries worked in 2018), shows the second most favorable growth pattern, i.e., growing employment as a combination of growing output and decreasing labor productivity.

Pharmaceutical industrial powers like the United Kingdom, Italy, and France (which are the second-, third-, and fourth-largest pharmaceutical employers in the Core EU) show less favorable development patterns: UK employment grows, but becomes less productive, while the Italian and French pharmaceutical industries become more productive, but their employment shrinks. Greece and the Netherlands are also in the same category as Italy and France, but as their weight in the Core EU pharmaceutical industry is low (the two together represent about $5 \%$ of pharmaceutical employment), even their significant employment decrease does not affect the whole Core EU group much. In contrast, Hungary's pharmaceutical industry represents a significant weight within the V4 countries (29\% of employees), and the pharmaceutical industry itself has a larger weight than the V4 average in the country's manufacturing industry.

The graphical representation of the evolution of an industry in different countries and comparing different periods allows one to identify development patterns. Countries that are closer together develop in a similar fashion. If countries in a country group are more spread out, their evolution is much more diverse.

The numbers in Table 2 and the two effects that explain the percentage change in the number of people employed in the pharmaceutical industry reveal important information about the development of the pharmaceutical industry. However, when assessing the points that signify each country and country group in the graphical representation above, the following factors should also be taken into consideration:

- How far (and in what direction) is a given point from the negative 45-degree straight line? A greater distance indicates a greater percentage change in pharmaceutical industry employment.

- To what extent does the position of the point change between the periods? Out of the 24 examined points, for five points, both coordinate components (labor intensity effect and sector growth effect) changed sign between the periods, i.e., the development pattern of the pharmaceutical industry substantially changed in several countries.

- How important is the country in terms of the pharmaceutical industry? For example, although Lithuania shows a spectacular three-fold increase in employment in the pharmaceutical industry between 2010 and 2018, it is still not particularly concerning from the perspective of the entire EU, given that only $1 \%$ 
of pharmaceutical industry employment within the PS9 countries is realized in Lithuania.

- How significant is the pharmaceutical industry within the country's manufacturing industry? For example, the Greek pharmaceutical industry employs a particularly high percentage of people employed in manufacturing (3\% in 2018, while the Core EU average is $1.9 \%$ ). Thus, even though the considerable decline there is not particularly important from the perspective of the entire EU, it is crucial for the country.

\section{Conclusions}

In the EU, manufacturing and high-tech manufacturing GVA have continuously increased, while employment has decreased since 2000. The new member states, the post-socialist countries, and the Visegrád countries, in particular, experience a GVA growth greater than the Core EU countries in both manufacturing and high-tech manufacturing, and their employment growth is also positive. The PS9 and V4 countries, therefore, have increased their share of manufacturing and high-tech manufacturing GVA and employment shares within the EU. By 2018, the Core EU countries were still 3.1 (2.6) times as productive in manufacturing and 3.5 (2.9) times as productive in the high-tech industries as the PS9 (V4) countries.

In the pharmaceutical industry, the GVA share has increased in the Core EU countries, but it is stagnant in the PS9 and V4 countries, while employment share has increased in each country group. In the Core EU, GVA and employment in the pharmaceutical industry both grew, and combined with continuing labor productivity growth, we could consider the growth intensive. On the other hand, in the PS9 and V4 countries, growth is more extensive. GVA increased because more people work, but efficiency - at least from 2010 on - hardly changed at all. Based on this, the pharmaceutical industry of the PS9 and V4 countries seems to be lagging behind rather than catching up with the pharmaceutical industry of the Core EU's - where this subsection already represents a greater weight both in manufacturing GVA and employment - which is rapidly improving in its efficiency. Consequently, improving labor productivity does not seem to pull up the pharmaceutical industry of the new member countries. 


\section{References}

Albu, N., Mecke, M., Ostwald, D.A., Zubrzycki, K. (2016), The Economic Footprint of Selected Pharmaceutical Companies in Europe, EFPIA - WifOR Research Report, https://www.efpia.eu/media/25820/the-economic-footprint-of-selected-pharmaceu tical-companies-in-europe.pdf (accessed: 12.07.2018).

Cantore, N., Clara, M., Lavope, A., Soare, C. (2017), Manufacturing as an engine of growth: Which is the best fuel?, "Structural Change and Economic Dynamics", 42 (9), pp. 56-66, https://doi.org/10.1016/j.strueco.2017.04.004

Coad, A., Vezzani, A. (2017), Manufacturing the future: is the manufacturing sector a driver of R\&D, exports and productivity growth?, "JRC Working Paper on Corporate R\&D and Innovation", No. 06, Joint Research Centre.

Cohen, W.M., Nelson, R.R., Walsh, J.P. (2000), Protecting their Intellectual Assets: Appropriability Conditions and Why U.S. Manufacturing Firms Patent or Not, "NBER Working Paper", No. 7552, https://doi.org/10.3386/w7552

ECORYS (2009), Competitiveness of the EU Market and Industry for Pharmaceuticals. Volume I: Welfare Implications of Regulation. Final report, https://publications.eu ropa.eu/en/publication-detail/-/publication/2c28ce31-3630-40e6-9743-006864229 bf4/language-en (accessed: 10.06.2018).

European Commission (2008), Safe, Innvative and Accessible Medicines: a Renewed Vision for the Pharmaceutical Sector, COM(2008) 666 final, Brussels.

European Commission (2010), EUROPE 2020. A strategy for smart, sustainable and inclusive growth, COM(2010) 2020 final, Brussels.

European Commission (2014), Pharmaceutical Industry: A Strategic Sector for the European Economy, Commission Staff Working Document SWD(2014) 216 Final/2, Brussels.

European Commission (2016), Communication from the Commission to the European Parliament, the Council, the European Economic and Social Committee and the Committee of the Regions. Digitising European Industry Reaping the full Benefits of a Digital Single Market, COM(2016) 180 final, Brussels.

Fujita, M., Thisse, J.-F. (2009), New Economic Geography: An appraisal on the occasion of Paul Krugman's 2008 Nobel Prize in Economic Sciences, "Regional Science and Urban Economics”, 39 (2), pp. 109-119, https://doi.org/10.1016/j.regsciurbeco .2008 .11 .003

Garattini, L., Curto, A., Freemantle, N. (2016), Pharmaceutical Price Schemes in Europe: Time for a "Continental" One?, "PharmacoEconomics", 34 (5), pp. 423-426, https://doi.org/10.1007/s40273-015-0377-5

http://ec.europa.eu/competition/sectors/pharmaceuticals/inquiry/communication_hu .pdf (accessed: 29.05.2018).

Malerba, F., Orsenigo, L. (2015), The evolution of the pharmaceutical industry, "Business History”, 57 (5), pp. 664-687, https://doi.org/10.1080/00076791.2014.975119

McMillan, M.S., Rodrik, D. (2011), Globalization, structural change and productivity growth, "NBER Working Paper”, No. 17143, https://doi.org/10.3386/w17143

Nagy B., Lengyel, I. (2016), The Structural Change of Manufacturing in Hungary, 20082014, "Studies in International Economics", 2 (2). pp. 3-27 
Presentation of the Preliminary Report of the Pharma Sector Inquiry (2008), http:// ec.europa.eu/competition/sectors/pharmaceuticals/inquiry/higgins.pdf (accessed: 29.05.2018).

Schweizer, S.O., Lu, Z.J. (2018), Pharmaceutical Economics and Policy. Perspectives, Promises and Problems, Oxford University Press, Oxford, https://doi.org/10.1093 /oso/9780190623784.001.0001

Tregenna, F. (2013), Deindustrialization and Reindustrialization, [in:] A. Szirmai, W. Naudés, L. Alcora (eds.), Pathways to Industrialization in the Twenty-First Century. New Challenges and Emerging Paradigms, Oxford University Press, Oxford, pp. 76-102, https://doi.org/10.1093/acprof:oso/9780199667857.003.0003

Vajda, B., Horváth, S., Málovics, J. (2012), Közös döntéshozatal, mint innováció az orvos-beteg kommunikációban, [in:] Z. Bajmócy, I. Lengyel, Gy. Málovics (eds.), Regionális innovációs képesség, versenyképesség és fenntarthatóság, JATEPress, Szeged, pp. 336-353

\section{Restrukturyzacja europejskiego przemysłu farmaceutycznego w latach 2000-2018}

Aby sprostać wymaganiom globalnej konkurencji, Unia Europejska (UE) kładzie szczególny nacisk na rozwój opartych na wiedzy, innowacyjnych branż. Przemysł farmaceutyczny, jako dział produkcji zaawansowanych technologii, ma w Europie długą tradycję. Jednak rozkład zatrudnienia i wartości dodanej w przemyśle farmaceutycznym nie jest równomierny w obrębie Unii, a jego rozwój w czasie jest również zróżnicowany. W niniejszym artykule dokonano analizy zmian struktury przemysłu farmaceutycznego w Unii Europejskiej w oparciu o grupy państw. Porównano rozwój zatrudnienia w branży farmaceutycznej w latach 2000-2018 w trzech grupach państw. Użyto prostej metody dekompozycji, aby oddzielić wpływ wzrostu sektora i zmiany wydajności pracy na zmiany zatrudnienia w przemyśle farmaceutycznym, aby dowiedzieć się, do jakiego stopnia podobnie ewoluowała ta branża w różnych grupach państw. Z analizy wynika, że o ile w 12 państwach będących członkami UE przed 2004 r. (Core EU) zatrudnienie nieznacznie wzrosło jednocześnie ze znacznym wzrostem wartości dodanej, to dziewięć państw postsocjalistycznych (PS9) osiągnęło łącznie nieco większy wzrost wartości dodanej przy znacznym wzroście zatrudnienia. W międzyczasie cztery państwa Grupy Wyszehradzkiej (V4) osiągnęły wzrost wartości dodanej podobny do PS9, ale jeszcze większy wzrost zatrudnienia. Wskazuje to na koncentrację części przemysłu farmaceutycznego o wyższej produktywności pracy w państwach Core UE, podczas gdy w słabiej rozwiniętych państwach postsocjalistycznych rozwija się część przemysłu farmaceutycznego o niższej wydajności pracy.

Słowa kluczowe: przemysł farmaceutyczny, wydajność pracy, wzrost, państwa Grupy Wyszehradzkiej 